Serap Yılmaz Özelçi

Necmettin Erbakan University
Original scientific paper

UDC: 37.013 .76

DOI: $10.5937 /$ IstrPed2102572Y

\title{
REMOTE VIEW OF EDUCATION, TEACHER, STUDENT AND SCHOOL CONCEPTS IN TEACHER TRAINING
}

\begin{abstract}
In this study, the experiences, feelings and thoughts of the instructors working in the teacher training program about distance education were examined. Therefore, the research is a phenomenological study. A focus group discussion was held. The study group of the research consisted of 5 volunteer lecturers. Faculty members criticize the university's preferred learning management system that allows limited communication. He argues that this provides opportunities for education rather than education. According to the instructors, the students perceived the individual learning preference, which is the most basic advantage of distance education, as irresponsibility rather than freedom. In summary, according to the instructors, interaction and role models are needed in the learning environment. In addition, technical and psychological preparation is important for a successful distance education.
\end{abstract}

Key words: Teacher training, Distance education, Phenomenology, Focus group interview.

\section{INTRODUCTOIN}

The aim of the education is to raise free individuals who have effective communication skills, adapt to change, access resources, use information and communication technologies efficiently, care about themselves and society, take responsibility, research, question and think critically. This is a universal goal and teachers are actors of this goal.The success of education systems depends on the quality and performance of teachers. The teacher should constantly improve himself and his teaching methods in line with the educational needs. For this reason, it is important to train qualified teachers and to train existing teachers about changing information and educational technologies. There are many methods used in teacher training. One of the ways countries use to meet the demands of qualified and internationally certified teachers quickly and effectively is distance education (Usta, 2015). DE (DE will be used for distance education from now on) is one of the most effective ways to provide lifelong learning at low cost, given its technical features and theoretical foundations (Isman, 2011; Kaya, 2002; Ozer, 1991). DI is education in which the learner and the teacher are in different places, the communication is provided with technological tools, and the education is organized in different environments. In other words; it is a planned teaching activity that supports learners' learning, controls them, includes the selection of teaching materials, the preparation and presentation of teaching, the learner and the teacher can be in different physical environments, and the education is carried out with technology (Moore \& Kearsly, 2011). Teachers were trained by DE in every period when the increasing need for teachers from past to present could not be met with face-to-face education (Gelisli, 2015; Ozer, 1991). It is the fastest way to train teachers especially in the Middle East, Latin America and African countries (ADEA, 2002; Kangai \& Bukaliya, 2011; Lyned, 2005; Murphy, Anzalone, Bosch, \& Moulton, 2002; Shohel, 2012). 
Governments and education ministries support distance teacher education for four reasons: rapidly increasing the proportion of teachers trained, limiting costs, retraining existing teachers, and improving learning conditions in primary schools (Lyned, 2005). Robinson and Latchem (2003) also stated that DI can be used in basic teacher education, in-service training, adaptation to changing training programs of teachers and teacher career development. In other words, qualified and internationally competitive teachers can be trained with DE (Fyle, 2013). The main condition for this is the quality of the DE offered. Murpfy et all (2002) explained the requirements of a successful DE as follows:

Learners need to receive adequate support about distance education, often through teachers or facilitators. The curriculum and materials must be high in quality and responsive. The program must be well designed to provide for sustainability in these ways: through a focus not on providing hardware but on meeting-learning goals and fitting to and enhancing the wider educational system; through building capacity within the host country; and through planning for the funding of low to moderate, but important, recurring program costs (Murphy et al. 2002: 1-4).

Ensuring the conditions for DE is extremely important. otherwise, both the DE will not be able to provide the expected efficiency and the opinions of the participants regarding the process will be negatively affected. Research shows that factors such as the characteristics of the learning management system (sound, image, enabling communication, etc.) or the duration of the course affect the perceptions of the participants about DE (Koppelman \& Vranken, 2008; Marsh, Mitchell, \& Adamczyk, 2010). While DE in teacher training is becoming more common day by day; The relationship between the basic features of distance education and the teaching profession is also discussed. It is thought that DE can be used in teacher education in a limited way. Because teacher training is a hands-on process that requires intense social interaction and behavioral training. It is considered important for the teacher candidate to be a role model in front of him. In this context, there is a need for studies examining DE in teacher training.

\section{METHOD}

\section{Research Design}

This research, which deals with the personal experiences of instructors on DE, is a qualitative phenomenology study. Phenomenological research describes the lived experiences of individuals about a phenomenon as described by participants (Creswel, 2007; Patton, 1990). In the current research, DE, which was conducted at a state university education faculty located in central Anatolia, was considered a "phenomenon" and a common meaning was tried to be deduced from the individual experiences of the instructors regarding this phenomenon. Data were collected through focus group interview. Focus group interviews are a qualitative research method that aims to learn about the psychological and socio-cultural characteristics of groups and subgroups that they are conscious, semi-conscious or unconscious about, their practices, and their behaviors and the reasons behind these behaviors (Yildirim \& Simsek, 2013).

\section{Study Group}

The study group of the research carried out in the spring semester of the 2019-2020 academic year consists of 5 instructors working at an education faculty in Central Anatolia. It consists of 17 lecturers who teach by distance education in the said faculty ( 1 lecturer is the researcher herself. Although the researcher herself gives lectures with distance education, she remained as an observer in the process and did not share any experience or comment). The aim and 
process of the research was explained to all instructors. 5 of them $(2 F, 3 M)$ formed the study group as a volunteer. Details of the study group are given in table 1.

Table 1. Descriptions of the study group

\begin{tabular}{clcccc}
\hline Code & Gender & Age & Seniority & Department & DE experience \\
\hline P1 & Male & 43 & 20 & $\begin{array}{l}\text { Computer and } \\
\text { Instructional } \\
\text { Technology }\end{array}$ & + \\
\hline P2 & Female & 41 & 12 & Turkish & + \\
\hline P3 & Male & 32 & $2($ TR $)+5($ USA $)$ & $\begin{array}{l}\text { Guidance and } \\
\text { Psychological } \\
\text { Counseling }\end{array}$ & + \\
\hline P4 & Male & 34 & 7 & Turkish & + \\
\hline P5 & Female & 36 & 14 & Elemantary Maths & - \\
\hline
\end{tabular}

\section{Data Collection Tools}

The Focus Group Interview Form was developed by the researcher. The questions were prepared based on the literature review and the researcher's individual observations in the process. The clarity of the questions and the accuracy of the expressions were checked. A pilot study was conducted by applying the draft form to 3 lecturers from outside the study group. The final form contains 4 basic and 12 explanatory questions (Appendix 1 ).

\section{Data Collection}

Research data were collected through focus group interviews. The study group was informed about the meeting day, time and the program to be used a week ago. The interview was conducted online (due to the pandemic) through the Cisco Webex program on June 4, 2020. A total of 123 minutes of interviews were recorded.

\section{Data Analysis}

First, it was made into text by watching video recording. Thirty-eight pages of raw data were obtained. Common meanings/concepts were tried to be determined by performing content analysis on these raw data. The researcher analyzed the data individually and then she compared her analyses to identify the emerging themes and categorize the data with another researcher's analysis. The coefficient of fit was calculated as .83 (this is an acceptable value for Miles \& Huberman) (Miles \& Huberman, 1994). While analyzing the data, member checking was conducted when the researcher felt the need to understand the participants better and overcome the ambiguities. The data were classified on the basis of the aspects investigated in the study. Following the initial coding, participants of the focus group were asked to check findings independently to ensure internal validity. Therefore, the categories were revised with the participants to guarantee reliability.

\section{III.FINDIGNS}

\section{Theme 1: Education-Instruction and Distance Education}

Participants asked whether they evaluated their DE process as education or instruction and the reasons for these evaluations. The distribution of the responses of the participants is given in Figure 1. Three instructors emphasize that there is an instruction. There is no communication 
and social/emotional sharing required for education, 1 instructor $\left(\mathrm{P}_{4}\right)$ defines the process as a training that occurs spontaneously rather than instruction because it is not planned, programmed and prepared.

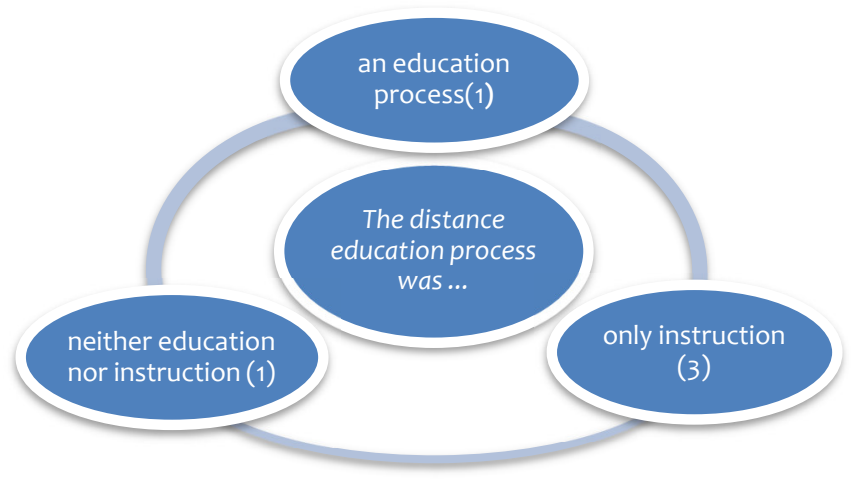

Figure 1: Opinions on the evaluation of the process as education or instruction

P5 stated that it was out of both situations, said "... Neither education nor instruction. Neither of them occurred in this process. We taught lessons but there were no students. Many did not watch the records. Interaction is required for education, and affective features should be brought to the fore. We have never been able to reach it. We saved the day that's all...". Another expression is:

P1: He (that's 10 weeks) wasn't a true DE. Did not meet the conditions of the DE. We only provided supplementary training.

Instructors were asked if they would like to experience this again in an environment where all the conditions required by DE were presented without any problems. While the instructors who survived the process more easily and whose course content was suitable for DI stated that they wanted to experience it again and were satisfied $\left(\mathrm{P}_{1}, \mathrm{P}_{3}\right)$, those who had technical problems $\left(\mathrm{P}_{2}, \mathrm{P}_{4}, \mathrm{P}_{5}\right)$ stated that they did not want to.

P4: I want to experience DI in an environment where there is sufficient technical infrastructure, the number of students is low, the financial situation of the students is sufficient for internet use, the students have the necessary technological tools, and attendance is compulsory. Do not interfere with us during the lecture, content and evaluation stages. Without these, DE is more tiring and boring.

Instructors were asked whether their technology aptitude or interest affected the process. All participants think that disposition and interest reflect positively and this directly affects the quality of teaching.

P2: Since all the trainers were caught unprepared for the process, there were individual differences in terms of access and use of technology. Those who are not interested in this subject (technology) and are not open to innovations have contributed to the disadvantage of the process, albeit unwillingly. 
P1: Of course, it would not be right to expect the same performance from everyone. In my opinion, instructors, who advanced age, could not handle this easily. It was not advantageous for students not to use the system and process effectively and efficiently.

\section{Theme 2: Teacher Role and Distance Education}

While teaching with $\mathrm{DE}$, the teachers were asked about their feelings. Participants defined their feelings as "satisfied and sufficient ( $\left.\mathrm{P}_{1}\right)$, relaxed ( $\left.\mathrm{P}_{3}, \mathrm{P}_{4}\right)$, uncomfortable ( $\left.\mathrm{P}_{5}\right)$, anxious and inadequate ( $\mathrm{P} 2$ ) (Figure 2). Then, "Would these feelings be the same if DE applications were started with a pre-planned schedule, if not for necessity?" asked. One instructor stated that this would affect their emotions positively ( $\left.\mathrm{P}_{4}\right)$, while two instructors stated that their emotions were already positive $\left(\mathrm{P}_{1}, \mathrm{P}_{3}\right)$. Two instructors stated that their feelings about the DE process would be negative no matter what (P2, $\left.\mathrm{P}_{5}\right)$.

Instructors were asked about the effects of DE on the teacher's role in the classroom. Although the general opinion is that the role of the teacher has changed/limited, the participants brought different interpretations to the subject. Here are the examples:

P4: I can say that the teacher reduced the role of supervising and managing. The student preferred the easy one. It was easier to control the student's behavior in face-to-face education, but I think that in DE, control was completely gone. The role of the teacher turned into a dimension that only lectures and someone that gives homework.

P2: Teacher, who managed the classroom like a maestro, turned into only the speaker. It was reduced to a position that is someone who teaches lessons in plain expression, does not get a response, is unable to measure and evaluate, and only knows.

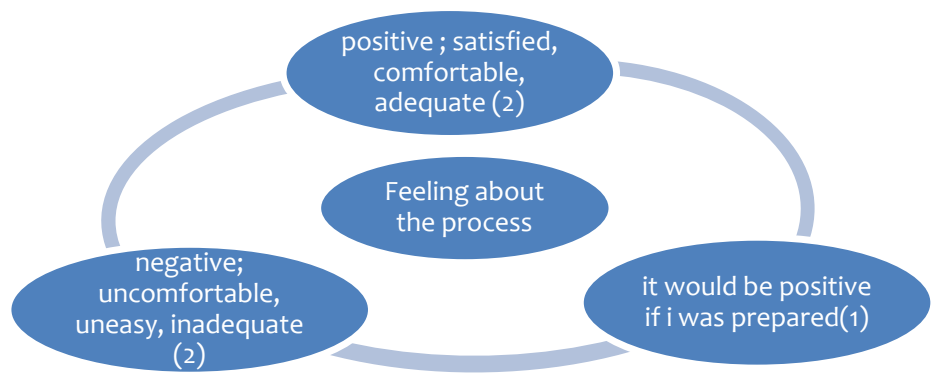

Figure 2: Expressions about how you feel while giving lectures

Participants were asked to compare their in-class roles during face-to-face and DE. It is seen that the lecturers draw attention to face-to-face education and emphasize that they do not have the opportunities they have in DE.

P1: Because we are training teachers, they could not see the behavior they would receive from us. This is a non-academic shortcoming. I think that our communication with the students in the affective sense is not fully established. 
P2: The main difference between the two courses is the lack of communication. Instead of asking questions, ask and tell immediately and give ready information. E.g; Instead of asking them to find out the theme of a story we read, I told it. I could not communicate with each other. We had an artificial process in which we presented everything ready-made and where we could not think mutually.

Instructors were asked how it felt to record lessons. All participants stated that being under the record was not a problem for them, but they emphasized that they paid attention to the choice of words in order to be understood correctly in an environment where there is no mutual communication. One of them said, ".... It was extremely repulsive and disturbing that the course was registered and the student didn't see us. Being watched and recording with the camera is not a pleasant feeling whereas in a face-to-face class, it is not annoying to receive guests or be listened to by the supervisor. That's why I felt like an amateur while teaching the lecture I recorded in front of the camera. What I experienced here was not knowing what to do, where to look, rather than a self-censorship. My attitudes and behaviors in the lesson did not change...P2"

Finally, the instructors were asked about their views on the effects of technological changes and transformations on the teaching profession. Three of the participants ( $\mathrm{P}_{1}, \mathrm{P}_{2}$ and $\left.\mathrm{P}_{5}\right)$ stated that the role of teachers would be permanent and that any change and transformation could only be a "supporting" factor. Two instructors $\left(\mathrm{P}_{3}, \mathrm{P}_{4}\right)$ think that the role of the teacher can be reduced and the concept of robot teacher can be realized.

P4: When I think of developing technology and artificial intelligence applications, maybe there will be no need for a teacher anymore. With the chips to be worn on people's heads, everyone will be able to learn everything easily. The need for the teacher will decrease further and everyone will be more isolated from each other.

P2: I do not think the education will be left to the robots, it sounds like a disaster scenario: The robot can only train a robot again.

P1: robots can come across by guiding student and helping teacher, but can't replace the teacher. The teacher will be. Robots can be considered a training agent.

\section{Theme 3: Student Role and Distance Education}

The instructors were asked how the student should be in DI and their thoughts on their students' experiences. All participants stated that the students abused the pandemic and the impossibilities (rural life, technological deprivations, not being able to access the internet) and that they could not really "benefit" from the process. Students perceived the process as flexible and without rules. A lecturer $\left(\mathrm{P}_{3}\right)$ evaluated this differently and said, “... the highly motivated students participated in the lesson internally and followed the lessons. Students who need external motivation could not benefit from educational opportunities in this process because the conditions to motivate them were not provided..." The summary explanation of the abovementioned statements is given in Figure 3. 


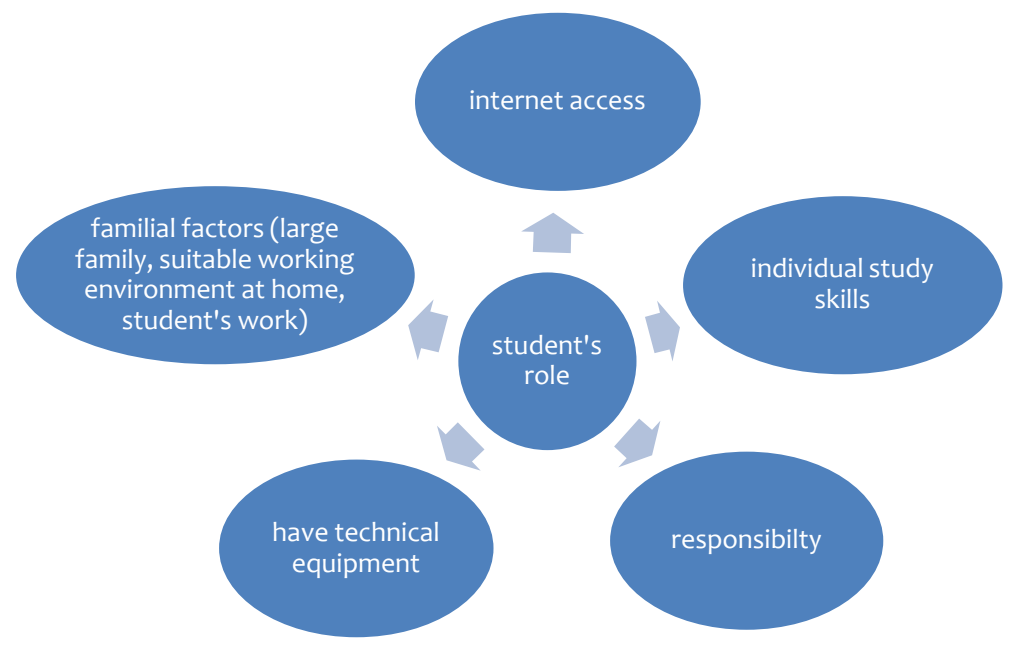

Figure 3: Factors affecting the student's role

All the participants think that both the instructors and students are caught unprepared and this affects both groups negatively. Instructors argue that in order for the students to benefit from the process effectively, there must be at least a "minimum" attendance requirement by providing the necessary technical structure by the university. Here are the examples:

P2: They followed DE first; then it's over. Of course, they couldn't get enough of this process. Students without technological material could not access the lessons. There are also those who have all kinds of opportunities but cannot attend the classes because they do not want to. Due to the inability of the instructors to adapt to the process, the motivation of the students also decreased.

P1: Due to the pandemic, the conditions were presented to students quite flexibly and they exploited it. The students are not aware of it, but it was a lost period for them. They couldn't take advantage of it as it was a fast transition.

P5: In the lessons, the students complained about the impossibility, emphasizing the negative effects of the pandemic and the decrease in the motivation of the lesson. I set up a session on Zoom. Even those who did not connect for 9 weeks were in that session. While we taught 40 minutes with 8-10 students, we chatted with 37 students for 1 hour.

\section{Theme 4: School and Distance Education}

Due to the transition to distance education in Turkey, both lecturers and students stayed away from the faculty. Faculty members who continue their studies at home were asked to think about the place of the faculties in their lives. First of all, they were asked whether school had any meaning other than being a workplace for them. Three lecturers stated that not going to school seemed comfortable, but it was actually uncomfortable because they did not define school as just a workplace. One of the trainers ( $\left.P_{5}\right)$ stated that "... going to school is a timeconsuming situation and he is satisfied with it". Here are other examples:

P2: School just not only a workplace but also a social environment I establish human relations. It is an environment consisting of my students and colleagues rather than the workplace and 
that makes me feel like I am part of a larger whole. I go there as a lifestyle, not in a workplace uniformity; because the teaching/guidance I do excites me.

P1: Academically, we have two-way tasks. The first is our own academic work, and the second is the information we must convey to students. Those are both emotionally satisfied us. School is not just a workplace but a place where relationships produce.

P3: District is small; our school smaller than it. We cannot learn anything new at any moment when we go, we cannot improve ourselves, but we are all human and social beings. It is important to chat with our peers and spend time there.

"Is a school necessary for the healthy execution of educational activities?" question has been asked. While four of the participants emphasized the necessity of school, one (P3) stated that the hybrid model could be used. He thinks that students can take distance education at home, but can come together for interactive lessons at schools on certain days of the week. K1 "I think school is a must. In the next period, DE can continue its complementary role. However, it does more harm than good to the faculty of education," he said.

Instructors were asked, "What is the sine qua non of an unschooled education?" All participants emphasized awareness. This awareness primarily includes teachers and students, then family and education administrators. They emphasized that all stakeholders should make a joint effort to achieve the goals of education. Here are the examples:

P3: Teachers should be knowledgeable and equipped on this subject. Because the teacher in DE should have knowledge in both the field and current technology. It is important to know the available possibilities and use them effectively. If the teacher is not aware of the technological possibilities, this is a loss for the student.

P2: An unschooled process needs to be planned very well. From the family to the teacher, everyone's areas of responsibility should be determined. Unschooling should not be regarded as irregularity or deviance. Even if they do not go to school, they should be made to feel that they are in the education process.

P4: Only in countries with sufficient technological infrastructure, materially and culturally developed, qualified people who can adapt to change can be trained in this way.

It is argued that students and instructors are liberated through DE (learning preferences, time intervals, independence of space, etc.). Instructors were asked for their opinions. They all agreed that illiteracy is freedom, but they emphasized that it can be perceived differently for the faculty member and the student, and that their losses and gains are combined.

P5: Yes, it provides freedom. However, besides academic education, there are also social life gains. Unfortunately, our students perceive freedom in the digital environment as copy-paste according to their wishes.

P2: Our experience has shown that deschooling is perceived as irresponsible. It gave students a sense of unlimited freedom. Most of them prefer to watch TV series on digital platforms instead of lectures.

Within the scope of the research, it was also asked whether access to unschooled education is related to socio-economic level. All of them stated that this is related to the socio-economic 
opportunities of both the individual and the country. They think that if there is sufficient opportunity and technological infrastructure, education can be reached at any time in any environment. After these explanations, it was reminded that another aim of the DE is to "provide equal opportunity in education" and their views on whether this was realized in the $\mathrm{DE}$ experiences were asked. All participants agree that this cannot be achieved in the current system. They said that many students living in rural areas without computers and smart phones and having problems with internet access could not receive education in this process.

P2: In our short experience, we saw that equal opportunities could not be achieved in DI. If a student in a remote village can reach the center without any problems, a model similar to the school can be followed. unschooled or distance education; since all these models consist of intertwined rings from state to individual; should be planned with all possibilities by the decision makers.

P3: Many of my students contacted me via e-mail or WhatsApp and asked for permission to upload their friend's homework. When I ask why, the answer is always the same. He does not have a computer; he wrote his homework by hand or his phone and internet package are not suitable for it. Equality was not possible.

$\mathrm{P} 4$ : As long as the technological infrastructure is not strong and socio-economic differences do not disappear, it is difficult to think of an education without school. There is absolutely no equality of opportunity. In developing countries like ours, this opens up the gap between students and eliminates equality. Individuality is also important in education. However, if everyone cannot benefit from this process equally, it is not individuality.

Finally, the instructors asked about their opinions on the effect of developing and changing technology on the school. All participants agree that they will be affected. But, they pointed out that this effect will have both positive and negative. They stated that teacher training could not be without interaction, so special arrangements could be made for the department and age group. Examples of participant opinions are:

P1: Certainly it will affect. It seems to be academically positive, opportunities are broad, and access will increase. In terms of gaining behavior, I believe that this change will be adversely affected. The school is also the prototype of social life, we should not lose it.

P4: It will affect. Step by step. There will definitely be a change in suitable lessons to the DE. Especially in postgraduate education, it should be common. However, I think that there should be no DE in primary or secondary school. These students have not reached a certain maturity or a certain mental stage. Socialization is damaged. In the undergraduate education, it should be at suitable lessons. Apart from these, it seems to me that it is against education to switch completely to DE.

\section{DISCUSSION}

In this phenomenological study, 10-week distance education experiences of teacher training instructors were examined. Emotions and thoughts about the process were discussed in the study group, which consisted of lecturers with and without experience about DE. Faculty members were asked to review the DI process in terms of the definition of education, the role of the teacher, the role of the student, and the function of the school. The participants' 'dramatic emphasis is on the changing teacher role and students' misinterpretation of the process.In addition, they emphasized that the quality of education decreased due to the 
variables they did not have and they could not receive education due to the lack of social interaction. The school has emerged as a used and missed environment for all participants to socialize and spend time with colleagues and students. On the other hand, participants evaluate the process according to the difficulties they experience. The technical difficulties in the process (sound, video problem, difficulty in sharing materials, internet interruption, etc.) or the course content not being suitable for DE caused negative experiences. Those who have relatively fewer problems during the process tend to re-use DE or hybrid model in education. Here, it can be thought that not only having problems in the process, but also having DE experience was effective. Experienced ones managed the crises that emerged more successfully. This can also be associated with the basic assumptions of DE. DE is not a model that can be started "suddenly". It requires a long technical background and content preparation time beforehand. The university, which is the subject of the research, has an DE center, but it is not active and the participants are not prepared for this situation. While the university activated this center quickly, the lecturers also tried to prepare appropriate content. Because in DE, how the content is prepared (clear, comprehensive) is more important than the presentation style.Especially in asynchronous lessons; When the student reads/watches alone, it should be clear enough to understand without causing confusion (Chao, Saj, \& Tessier, 2006). Therefore, it should be prepared meticulously. The fact that the instructors did not have enough time and experience on this subject increased the workload. In addition, faculty members in DI need to deal with new teaching approaches, technology, guidance, support and emerging problems in the process (Gurer, Tekinarslan, \& Guralp, 2016). However, they did not receive any training in this regard. The lack of in-service training on online teaching methods and techniques may have caused the instructors to develop negative opinions about the process (Bolliger \& Wasilik, 2009).In higher education, the perspective of the instructor, the views and satisfaction regarding DE are important for effective and efficient DE (Harris \& Krousgill, 2008; Dooley \& Murphey, 2000). OECD asked 330 education employees and stakeholders from 98 countries about the most important educational problems in the pandemic. $77.9 \%$ of the participants stated that there should be professional support for teachers and $77.6 \%$ stated that they want the teachers to be well (OECD, 2020).

The history of DE in teacher training who create such anxiety in teaching staff is old. DE was used whenever more teachers were needed than they could be trained in the face-to-face. Perhaps the first organized distance teacher training effort was, in the 1960 s when UNESCO set up an institute of education to train Palestinian refugee teachers. With this institute, the rate of uneducated teachers fell from 90 percent to 9 percent in 5 years (Lyned, 2005). This process, which started with Palestinian immigrants, has turned into another form today. It is an in-service training as part of lifelong learning. Simultaneously, it is on the agenda to be used alone or mixed in teacher training. Because the need for qualified teachers is among the basic education needs. According to the UNESCO Institute of Statistics (UIS), 69 million teachers should be recruited to achieve universal primary and secondary education by 2030 (UNESCO, 2020). For this reason, DE or hybrid models inevitably appear in teacher education. Higher Education in Turkey as well, the proportion of DE courses can be given has increased to $40 \%$ from $30 \%$ (CHE, 2020).

Considering the evaluations made in the context of teacher role and student role, all participants think that their roles are limited. This limitation stems from both the limits drawn by the DE and the lack of motivation of the students. University used Adobe Connect program. The version used does not allow the lecturer to see the student and offers a microphone and chat for communication and left the attendance to the student initiative. In an environment where there is no compulsory attendance, the lecturer cannot see what the student is doing or what they are interested in, the absence of students or the choice to follow the lessons in 
record, has turned the teacher into content transfer. According to the Jung, Horta \& Postiglione (2021) if the only positive side of this situation is some students appeared comfortable raising questions with the teacher using the chat protocol.

Considering the student role, the general view is that students behave reluctantly and do not use the process effectively. Especially the decisions made by the decision makers in favor of the students (technological impossibilities, not forcing students due to the pandemic) created an unfounded self-confidence. With this self-confidence, they either did not follow the synchronous lessons or attended the lesson. The common problem of all participants is the way the lecture is done on the wall. Students' not getting used to the new learning process and not having the necessary qualifications to benefit from DI may have negatively affected their participation and academic performance (Johnson, 2008). In this process, only students who are internally supervised and trying to learn can progress cognitively, but even if others successfully complete the term, they are not considered to have learned the presented content. Opinions on how the school will be affected by changing educational technologies have been similar. All the instructors stated that no matter where the technology reaches, no training process such as teacher training can be $100 \%$ at the computer, and there must be a face-to-face part. This suggests that the school will always protect its existence as an area of socialization and interaction. However, while making this comment, the contributions of DE or reasons for preference should not be forgotten. There should be a school, but it should be DE for individuals who cannot reach this school for any reason. Providing equal opportunities in education and education for everyone is among the basic claims of DE (Fyle, 2013; ADEA, 2002, Kaya, 2002). However, this goal can be achieved by providing government support and equal access to all individuals. In cases where the rural population is dense, education is possible for everyone and access for everyone.

DE has a long history in teacher training. It is an education model that replaces or supports faceto-face education in Turkey, especially during crises. While the trainers talk about the difficulties and problems of the process, they do not deny that the crisis has a solution. It is thought that it will take its place as a hybrid model in the education system based on the experience gained by its implementation throughout the country.

\section{CONCLUSIONS and SUGGESTIONS}

In this research, in which distance education practices in the teacher training process are handled in line with the knowledge, thoughts and experiences of the practitioner instructors; perspectives on the advantages and disadvantages of distance education are presented. Although it is emphasized that teacher education cannot be realized without communication and social interaction, attention is drawn to the possibility of hybrid learning. The general results and recommendations based on these results are as follows:

- Participants consider that the most basic problem is that the learning management system preferred by the rectorate does not allow teacher-student interaction. The learning management systems preferred by universities and the technical infrastructure they offer are decisive in the efficiency of the process. For this reason, applications that allow the active participation of the student (audio + video) should be preferred.

- Participants said that they were left alone with their individual competencies regarding distance education; they emphasized that those who have knowledge and inclination can adapt to the process easily, but those who are in the opposite situation have difficulties. In this context, training should be given to the instructors about the use of the system and the method techniques that can be used in distance education before the application. 
- The participants stated that the concepts of self-awareness and self-control are the basis of distance education. The student must manage the learning time and process. In order for students to get maximum benefit from the process, awareness/directions should be made regarding individual study and learning skills.

- The features of the learning management system should be explained to the students in detail.

- Since affective elements cannot be ignored in teacher education, face-to-face environments must be designed.

\section{APPENDIX 1}

\section{Instructor Interview Form}

1.Egitim ve Uzaktan Egitim

- Uzaktan "egitim"mi, ogretim mi? Yasadiginiz sureci nasil tanimlarsiniz? Neden?

- Eger sorunsuz bicimde isleyen bir uzaktan egitim altyapisina sahip olsaniz (ornegin ogrencilerin de surece dahil olabildigi bir program kullanilsa, dosya ekleme ve veri paylasimi, olcme degerlendirme alanlari sizin tercihleriniz dogrultusunda sekillense vs vs), derslerinizi yurutmede tekrar benzer bir deneyim yasamak ister miydiniz? Nicin?

- Yasadigimiz bu surecte ogretim elemani ile ilgili bireysel farkliliklardan kaynaklanan (teknoloji yatkunligi, ilgililik, tecrube, vs. ) avantaj ya da dezavantajlar olabilir mi?

oSoz konusu avantaj ya da dezavantajlar surecin egitim ya da ogretim olarak tanimlamanizda rolu oldugunu dusunuyor musunuz?

2. Ogretmen ve Uzaktan Egitim

-Yasadiginiz deneyim surecinde "ogretmen" olarak kendinizi nasil hissettiniz (rahat / rahatsiz, memnun / memnuniyetsiz, tedirgin / guvenli, yeterli / yetersiz)?

oBu his yuz yuze egitimdeki hislerinizden farkli miydi? Eger farkli ise sizce bu farkin kaynagi / sebebi ne?

- Yuz yuze egitimle islediginiz bir dersinizi ve uzaktan egitimle islediginiz bir dersinizi dusunmenizi istiyorum. Iki ders arasındaki en temel farkluiliklar neler?

- Derslerin kayit altinda olmasi size ne hissettirdi? Bu durumun dersteki tavir, tutum ve davranıslariniza yansidigini dusunuyor musunuz?

- Surec zorunluluk olarak baslamasaydi da kendiliginden / sizin tercihinizle ortaya cıksaydi farkli tutum ve davranıs icerisinde olur muydunuz?

- Ogretmenin sinif icindeki rolunu nasil tanimladiginizi dusunun. Uzaktan egitimin bu rolunuzu etkiledigini ya da degistirdigini dusunuyor musunuz?

oBu etki ya da degisim sizce ilerleyen zamanlarda bir zorunluluk olarak karsiniza cıkabilir mi? Pandemi de ikinci dalga / egitim ogretim reformu vs vs

- Yapay zeka tum dunyada en cok para harcanan arastirma konusu. Yapay zeka kavrami robot ogretmeni de gundeme getirmekte. Yapay zeka uygulamalarının mesleginizin gelecegine etkisi hakkinda neler dusunuyorsunuz?

3. Ogrenci ve Uzaktan Egitim

- Uzaktan egitim surecinde ogrencilerinizin tutum ve davranislarini nasil degerlendirirsiniz?

- Ogrencilerin uzaktan egitim hizmetinden yeterince faydalanabildiklerini dusunuyor musunuz? Nicin?

oSizce bu durumun (faydalanma ya da faydalanamama) sebepleri neler?

- Surec zorunluluk olarak baslamasaydi da kendiliginden ortaya cıksaydi farkli tutum ve davranıs icerisinde olurlar miydi?

- Ogrencilerin derse katilim / devam zorunluluklarının olmamasi konusunda ne dusunuyorsunuz?

4.Okul ve Uzaktan Egitim 
- Okul kurumu sizin icin "isyeri” olmanin disinda farkli anlamlar da barindiriyor mu? Ornegin?

- Yasadıginiz tecrubeden hareketle sizce egitim-ogretim faaliyetlerinin saglıklı bicimde yurutulebilmesi icin "okul" sart mi?

- Okulsuz yonetilecek bir egitim-ogretim surecinin olmazsa olmazlari nelerdir?

- Okulun olmadigi bakis acılarinda ogrencilerin ve ogretim elemanlarinin okulsuz ozgurlestikleri savunulmaktadir (ogrenme tercihleri, okulda gecirilen zamanin kendisine kalması vs vs). Uzaktan egitim uygulamalarının oghrenciyi ozgurlestirmesi soz konusu olabilir mi?

oBenzer durum ogretim elemanlar icin de soz konusu mudur?

- Okulsuz bakis acisi okulun sosyo-ekonomik farkliliklari yeniden urettigini savunmaktadir. Ogrencilerin sahip olduklari imkanlar dogrultusunda egitim alabildikleri vurgulanmaktadir. Sizce bu durum uzaktan egitimde kendini nasil gosterir? Uzaktan egitimin sosyo-ekonomik imkanlarla iliskisi var midir?

oPeki bu durum uzaktan egitimin faydalari basligi altinda sunulan ogretimin bireyselligi, egitimde fırsat esitligi ozellikleriyle iliskisini nasil acıklariz?

- Sizce gelisen uzaktan egitim teknolojileri ya da olası egitim reformları kurum olarak "okul"u etkileyecek mi? Etkileyecek ise nasıl etkileyecegini dusunuyorsunuz?

\section{REFERENCES:}

Association for the Development of Education in Africa (ADEA) (2002). Distance education and open learning in sub-Saharan Africa: A literature survey on policy and practice. Working Group on Distance Education and Open Learning. Reduit: Maritius, ADEA.

Bolliger, D. \& Wasilik, O. (2009). Factors influencing faculty satisfaction with online teaching and learning in higher education. Distance Education, 30(1), 103-116.

Chao, T, Saj, T., \& Tessier, F. (2006). Establishing a quality review for online courses. Educause Quarterly, 3 (1), 32-39

Counsil of Higher Education (CHE) (2020). Press briefing. Retrieved March 26, 2020 from https://www.yok.gov.tr/Sayfalar/Haberler/2020/.

Creswell, J. W. (2007). Qualitative inquiry \& research design: Choosing among five approaches (2nd ed.). SAGE Publications.

Ciftci, E. (2008). Examination of in-service teacher training given to music by the Ministry of Education in Turkey and Determination of music teachers in-service training needs. Unpublished doctorate dissertation, Gazi University Educatioanal Sciences Institue, Ankara.

Dooley, K. E. \& Murphrey, T. P. (2000). How the perspectives of administrators, faculty, and support units impact the rate of distance education adoption. Online Journal of Distance Learning Administration, 3(4), 1-1.

Fyle, C.O. (2013). Teacher education MOOCs for developing world contexts: Issues and design considerations, Sixth International Conference of MIT's Learning International Networks Consortium (LINC), June 16 - 19, 2013 Cambridge, Massachusetts.

Gelisli, Y. (2015). Teacher training practices in distance education: History and development, Journal of Research in Education and Teaching, 4 (3), 313-321.

Gurer, M. D., Tekinarslan, E. \& Yavuzalp, N. (2016). Online course instructors' views on distance education. Turkish Online Journal of Qualitative Inquiry (TOJQI), 7 (1), 47-78.

Harris, D. A. \& Krousgrill, C. (2008). Distance education: New technologies and new directions. Proceeding book of The Institute of Electrical and Electronics Engineers, 96(6), 917-930.

Isman, A. (2011). Uzaktanegitim [Distance education] (3.edt). Ankara: Pegem Academy Publisihing.

Johnson, G. (2008). The relative learning benefits of synchronous and asynchronous text based discussion. British Journal of Educational Technology, 39 (1), 166-169. 
Jung, J., Horta, H. \& Postiglione, A. G. (2021). Living in uncertainty: the COVID-19 pandemic and higher education in Hong Kong. Studies in Higher Education, 46 (1), 107-120.

Kangai, C. \& Bukaliya, R. (2011). Teacher development through open and distance learning: the case for Zimbabwe. International Journal on New Trends in Education and Their Implications, 2 (4), 124-141.

Kaya, Z. (2002). UzaktanEgitim [Distance education], Ankara: Pegem Academy Publishing.

Koppelman, H., \& Vranken, H. (2008). Experiences with a synchronous virtual classroom in distance education. Proceedings of the 13th annual conference on Innovation and technology in computer science education (pp 194-198), ITICSE'08 Madrid.

Lynd, M. (2005). Fast-track teacher training models for consideration for Southern Sudan, as a report written for the American Institutes of Research and the Sudan Basic Education Program.

Marsh, B., Mitchell, N., \& Adamczyk, P. (2010). Interactive video technology: Enhancing professional learning in initial teacher education. Computer \& Education, 54(3), 742748.

Miles, M. B., \& Huberman, M.A. (1994). Qualitative data analysis. Beverly Hills, CA: Sage.

Moore, M.G. \& Kearsley, G. (2011). Distance education: A system view of learning (3th edition). Wadshworth: Cengage Learning.

Murphy, S., Anzalone, S., Bosch, A. \& Moulton, J. (2002) Enhancing learning opportunities in Africa: Distance education and information and communication technologies for learning. Washington DC: World Bank, March 2002.

Organisation for Economic Co-operation and Development (OECD) (2020). A framework to guide an education response to the COVID-19 Pandemic of 2020. Retrieved March, 17, 2020 from https://read.oecd-ilibrary.org/view/?ref=126_126988-t63lxosohs\&title=Aframework-to-guide-an-education-response-to-the-Covid-19-Pandemic-of-2020

Ozer, B. (1991). Using the distance education approach in teacher education, Journal of Anadolu University Faculty of Education, 4 (1-2), 73-88.

Patton, M. Q. (1990). Qualitative evaluation and research methods (2nd ed.). Newbury Park, CA: Sage.

Robinson, B. \& Latchem, C. (2003). Teacher education through open and distance learning. London: Routledge

Shohel, M. (2012). Open and distance learning for teachers' professional development: The English in action (EIA) model for the Global South, International Perspectives of Distance Learning in Higher Education, 1(1), $x-x$.

Usta, i. (2015). Suggestions for the evaluation and development of the open education faculty social sciences associate degree program. Unpublished doctorate dissertation, Anadolu University, Social Sciences Institu, Eskisehir.

United Nations Educational, Scientific and Cultural Organization (UNESCO) (2020) Pandemic report. Retrieved June, 20, 2020 from http://www.unesco.org.tr/Pages/48/10/E\%C4\%9Fitim

Yildirim, A. \& Simsek, H. (2013). Qualitative research methods in the social sciences. (9.editon). Ankara: Seckin Publication.

\section{Biographical notes:}

Asistant Prof. Serap Yılmaz Özelçi is a faculty member at Necmettin Erbakan University, Ereğli Faculty of Education. Her scientific interests/areas of study include critical thinking and teaching, thinking education, philosophy of education, curriculum development, and teacher education. 